
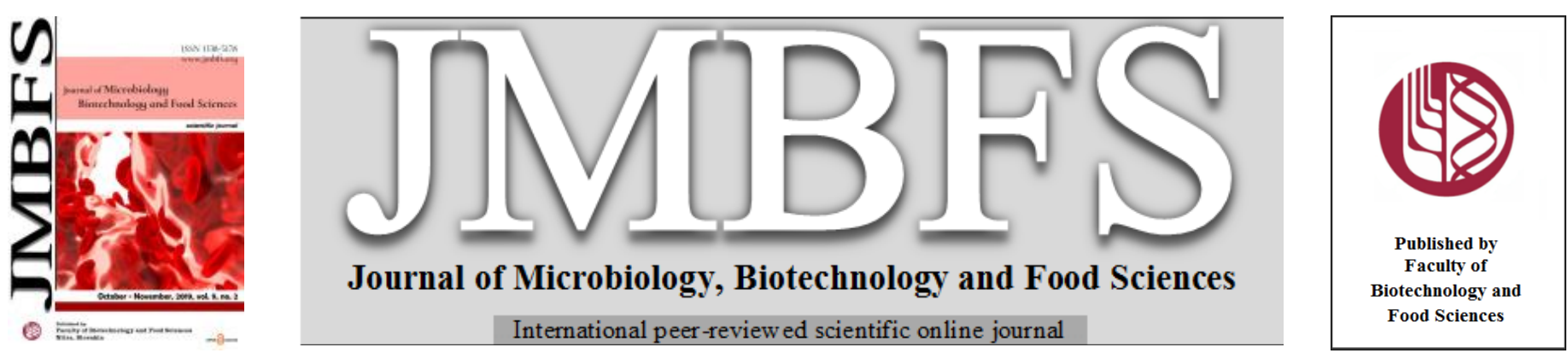

\title{
COMBINED EFFECT OF EUCALYPTUS MICROCORYS AQUEOUS EXTRACT AND LIGHT ON PATHOGENIC ESCHERICHIA COLI SURVIVAL IN AQUATIC MICROCOSM
}

\section{Antoine Tamsa Arfao ${ }^{1,2}$, Olive Vivien Noah Ewoti ${ }^{2}$, Mamert Fils Onana ${ }^{3}$, Chretien Lontsi Djimeli ${ }^{2}$, Simeon Tchakonté ${ }^{1}$, Nathalie Kobbe Damal, Moïse Nola ${ }^{2}$}

$\operatorname{Address}(e s)$ :

${ }^{1}$ Microbiology and Biotechnology Laboratory, Saint Jerome Polytechnic Institute, Saint Jerome Catholic University of Douala, P.O. Box 5949 Douala, Cameroon.

${ }^{2}$ Hydrobiology and Environment Laboratory, University of Yaoundé 1, Faculty of Sciences, P.O. Box 812, Yaoundé, Cameroon.

${ }^{3}$ Department of Aquatic Ecosystems Management, Institute of Fisheries and Aquatic Sciences, University of Douala, Douala, Cameroon.

*Corresponding author: tamsarfao@yahoo.fr

doi: 10.15414/jmbfs.2020.9.5.1003-1008

\section{ARTICLE INFO}

Received 10.3. 2018

Revised 25. 11. 2019

Accepted 10. 12. 2019

Published 1. 4. 2020

Regular article

OPEN $\partial_{\text {ACCESS }}$

\begin{abstract}
Microcosm experiments were carried out to investigate the effect of Eucalyptus microcorys aqueous plant extract on pathogenic Escherichia coli survival in water. The results clearly showed that the combined effect of light and extract concentration impacted significantly survival of the bacteria. The dark inhibition coefficient $\left(K_{D}\right)$ was $0.102 \mathrm{~h}^{-1}, 0.116 \mathrm{~h}^{-1}, 0.111 \mathrm{~h}^{-1}, 0.123 \mathrm{~h}^{-1}, 0.136 \mathrm{~h}^{-1}$ and $0.146 \mathrm{~h}^{-1}$ with $0.05 \%, 0.1 \%, 0.5 \%, 1 \%, 1.5 \%$ and $2 \%$ of extract concentration respectively. In the light conditions, we noted a relative increase of light inhibition coefficient $\left(K_{L}\right)$. The Self-Organizing Map according to incubation duration of cells in the extract solution permitted to group bacterial abundances in three clusters. Cluster I is the abundance of cells registered after 24 hours incubation in the plant extract solution. Cluster II is made up of all cells abundances registered after 9 and 12 hours incubation and Cluster III is constituted by cells abundances obtained after 3 and 6 hours incubation. Globally, for extract concentration 1, 1.5 and 2\%, a calculation using Chick-Watson model resulted to a value of $\log (\mathrm{N} / \mathrm{No})=-0.1 \mathrm{Ct}$ which is very close to chlorine disinfectant Chick-Watson model $\log (\mathrm{N} / \mathrm{No})=-0.16 \mathrm{Ct}$. These results can improve in the new alternative method of treatment water by plant extracts.
\end{abstract}

Keywords: Eucalyptus microcorys, aqueous plant extract, light, pathogenic Escherichia coli, inhibition, aquatic microcosm

\section{INTRODUCTION}

The problems of water supply for households in developing countries constitute nowadays, an important challenge to contribute to a sustainable development while guaranteeing satisfactory sanitary health. In spite of the Millennium Development Goals (MDG), many countries don't have access to drinking water (Sunda, 2012). 13\% of the world's population, approximately 884 million people, lack access to an improved drinking water source (WHO/UNICEF, 2010). Fresh water is threatened by rising consumption and multiple pollutions. Bacteria responsible for the microbiological water pollution include Salmonella, Escherichia and Vibrio among others (WHO, 2004). The presence of Escherichia coli specie in water is probably a sign of the deterioration of its quality, due probably to contamination by pathogenic strict or opportunistic pathogens (CEAEQ, 2004). For nearly a decade, numerous epidemics attributed to pathogenic E. coli strains are regularly reported in the world (Germani and Le Bouguénec, 2008). Ingestion of contaminated water due to lack of hygiene and unsanitary water, sanitation and hygiene, contributes to about 1.5 million child deaths per year and around $88 \%$ of them from diarrhea (WHO, 2002). In many countries of the world, the need for disinfected drinking water already constitutes a huge problem (Bergmann et al., 2002). Traditionally, chlorine is the most widely used chemical compound for water disinfection in many water treatment plants.

However, the production of by-products of chlorination such as halogenated organic compounds, has been shown to be associated with various ailments in humans (Hwang et al., 2008). The combined effect of sunlight and temperature on bacterial cells is responsible for their inhibition in the solar irradiation process (Reed, 2004). Although the methods of disinfecting water by boiling, by adding chemicals or sunlight have their merits, but the slightest negligence in this area can lead to severe gastrointestinal illness and even death in children or immunodeficient people. According to literature, Medicinal plants are used by more than $80 \%$ of African and Asian households for therapeutic purposes. Indigenous people use hundreds of plants to treat themselves (Weathers et al., 2014). Recently, studies have been focused on treatment of water with plant extracts. Studies have shown that some aqueous extracts of Hibiscus rosa- sinensis, Cymbogon citratus and Lantana Camara, have a bactericidal effect in the aquatic environment (Sunda et al., 2008). They also showed that the combined action of light and Artemisia annua extract inhibit growth of Enterococcus faecalis cell (Mobili et al., 2015). However, the use of aqueous plant extract in the process of water disinfection, destined to drinking, remains low. Little information is available on the synergistic effect of light intensity and aqueous extract of Eucalyptus microcorys on planktonic cells of pathogenic Escherichia coli in aquatic microcosms. Few information is also available on the impact of various extract concentrations of Eucalyptus microcorys on bacteria, likewise few information relates the influence of the aqueous extract of E. microcorys on bacteria with respect to the duration of exposition under light intensity. This study aims to evaluate in aquatic microcosm, the combined impact of light intensity and the duration of exposure to photons on the inactivation of pathogenic Escherichia coli under different concentration of aqueous extract solution of Eucalyptus microcorys.

\section{MATERIAL AND METHODS}

\section{Preparation of E. microcorys Leaf Crude Extract}

Fresh leaf samples of E. microcorys were harvested in Yaoundé, Center Region (Cameroon) and dried up at room temperature $\left(23 \pm 2^{\circ} \mathrm{C}\right)$ in the laboratory for 30 days (Tamsa Arfao, 2017). Dried samples were ground (for 2 mins) to fine powder $(<200 \mu \mathrm{m})$ using a laboratory grinder at maximum speed. Fifty grams of the powder obtained, were mixed with $100 \mathrm{ml}$ of hot distilled water. This mixture was boiled for thirty minutes in a conical flask. The extract was filtered through Whatman filter paper number 1 . The filtrate obtained constituting the decoction, was dried in an oven at $45-50^{\circ} \mathrm{C}$ (Tamsa Arfao et al., 2013). The obtained crystals were used to prepare the crude extract. Six extract concentrations $0.05 \%, 0.1 \%, 0.5 \%, 1 \%, 1.5 \%$ and $2 \%$ were prepared thus while using sterile physiological water. Every concentration was filtered with nitrate cellulose membrane of $0.45 \mu \mathrm{m}$ porosity.

Qualitative phytochemical screenings were done according to the standard protocols. Alkaloids test was done according to Dragendorff's and Meyer's 
tests, whereas Barfoed's and Fehling tests were used for carbohydrates. The reduction of $\mathrm{FeCl}_{3}$, the frothing and Salkowski tests allowed to screen flavonoids, tannins, saponins and terpenoids respectively (Trease and Evans, 1983; Sofowora, 1993; Mobili et al., 2015).

\section{Isolation and identification of pathogenic Escherichia coli}

This bacterium was isolated from the urban stream in the Center Region of Cameroon. It was isolated on Endo medium, using membrane filtration technique at $44^{\circ} \mathrm{C}$ for 24 hours (Rompré et al., 2002). Bacterial colonies with metallic green sheen observed on Endo medium were identified according to standard method (Holt et al., 2000). These biochemical tests are performed on conventional galleries consisting of media introduced in tubes. The identification of the bacterial strain is obtained by comparing its biochemical profile with those pre-established in the API20E Biochemical Test. These tests are grouped into basic and orientation tests for the confirmation diagnosis of Escherichia coli strains. Characterization of E. coli was done according to Nougang et al. (2011) protocols.

\section{Preparation of pathogenic Escherichia coli culture}

For the preparation of bacterial stocks, a colony forming unit (CFU) from Endo medium was inoculated into $100 \mathrm{~mL}$ of nutrient broth (Oxford) for $24 \mathrm{~h}$ at 37 ${ }^{\circ} \mathrm{C}$. After this period, cells were harvested by centrifugation at $8000 \mathrm{rev} / \mathrm{min}$ for $10 \mathrm{~min}$ at $10^{\circ} \mathrm{C}$ and washed twice with $\mathrm{NaCl}(0.85 \%)$ solution. Each pellet was re-suspended in $50 \mathrm{~mL}$ of $\mathrm{NaCl}$ solution. After homogenization, $1 \mathrm{~mL}$ of the obtained solution was then transferred into $500 \mathrm{~mL}$ of sterile $\mathrm{NaCl}$ solution $(0.85 \%)$ in Erlenmeyer flask and stocked.

\section{Experimental process}

For this experimentation, 35 flasks of $350 \mathrm{~mL}$ were used. They were organized into seven series of five flasks: A, B, C, D, E, F and G. $200 \mathrm{ml}$ of physiological water at $0.85 \%$ of $\mathrm{NaCl}$ concentration were used for control tests and were considered as the A serie flasks The six other series namely B, C, D, E, F and $\mathrm{G}$ contained $200 \mathrm{~mL}$ of the extract at different concentrations $0.05 \%, 0.1 \%$, $0.5 \%, 1 \%, 1.5 \%$ and $2 \%$ respectively. The concentrations chosen were based on our previous work (Tamsa Arfao et al., 2013) and according to Nicolas (2012) recommandations. At initial time $\mathrm{T} 0,1 \mathrm{~mL}$ of the inoculum was transferred in to each flask. At $\mathrm{T}_{0}$, the cell concentration was $27 \times 10^{8} \mathrm{CFU} / \mathrm{mL}$. The contact times were $3,6,9,12$ and 24 hours. The light intensity was of the order of 0 1x (darkness condition), 1000 lx, 2000 lx and 3000 lx (light condition). Our experimentation microcosms were subjected to illumination provided by $100 \mathrm{~W}$ Tungsten filament lamps (TESLA HOLE-SOVICE) (Nola et al., 2010). A lamp was placed at $25 \mathrm{~cm}$ above each water solution. The 4 lamps were connected in series on a single cable, itself connected to a variable rotary brightness (Voltman). A luxmeter (PHYWE) was used to measure the light intensity reaching the bottom of each container. The electrode of the luxmeter was immersed in the container. Figure 1 depicts the experimental setup used for this study. Bacteriological analysis was performed for each incubation duration.

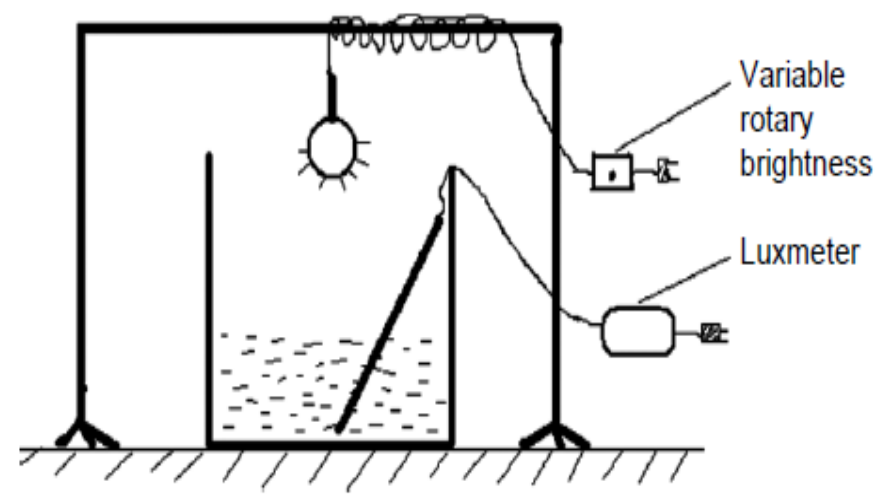

Figure 1 Experimental setup showing the process used (Nola et al., 2010).

\section{Data analysis}

The variation patterns of pathogenic $E$. coli cell abundances at different concentrations of Eucalyptus microcorys aqueous extract $(0.05 \%, 0.1 \%, 0.5 \%$, $1 \%, 1.5 \%$ and $2 \%$ ) and different experimental conditions (darkness condition, intensity light at $1000 \mathrm{~lx}, 2000 \mathrm{~lx}$ and $3000 \mathrm{~lx}$ ) were displayed using the SelfOrganizing Map (SOM) by means of the toolbox developed for Matlab (Alhoniemi et al., 2003). After living in the extract solution of Eucalyptus microcorys at different concentration and incubation duration, the cell abundances were arranged as a matrix of 5 rows (corresponding to the different hours of incubation of cells in the extract solution: 3, 6, 9, 12 and 24 hours) and 24 columns. The Self-Organizing Map algorithm was then applied to classify samples in each group according to their similarity in terms of cell abundances. Self-Organizing Map preserves neighborhood so that samples with similar abundance values are grouped together on the map, whereas samples with very different abundances are far from each other.

The percentage of inhibition (PI) was calculated using the following formulae as described by Tamsa Arfao et al. (2013).

$$
P I=\left(\frac{N o-N n}{N o}\right) \cdot 100
$$

where $\mathrm{N}_{0}=$ cell abundance in control $(\mathrm{NaCl}: 0.85 \%) ; \mathrm{N}_{\mathrm{n}}=$ cell abundance after the action of extract solution.

According to the first 12 hours of contact time with extract concentration, the straight $\mathrm{Ln}$ of the form $\mathrm{y}=\mathrm{ax}+\mathrm{b}$ were plotted for each considered parameters. In this equation, $\mathrm{x}$ is the explanatory variable and $\mathrm{y}$ is the dependent variable, $a$ is the slope of the regression line, and $b$ is the intercept point of the regression line on the $y$ axis (the value of $y$ when $x=0$ ) (Tofallis, 2009). The slope of the straight line was then considered as the dark inhibition coefficient $\left(K_{D}\right)$ in dark condition and light inhibition coefficient $\left(K_{L}\right)$ in light condition.

The rate of disinfection as described by the Chick-Watson equation was used to compare the data obtained after combined effect of the extract concentration and the reaction time. Generally, disinfection models are established with $\mathrm{Ct}$ values derived from Chick-Watson kinetics based on the values obtained in laboratory inhibition studies (Sunil and Nitin, 2012). This Watson function was done using Excel program of the following form: $\log (\mathrm{N} / \mathrm{No})=-\mathrm{K} \mathrm{C}^{\mathrm{n}} \mathrm{t}$ (Chick 1908; Watson 1908).

In many cases, the $\mathrm{n}$ value for Chick-Watson law is close to 1.0 and hence a fixed value of the product of concentration and time (Ct product) results in affixed degree of inactivation (AWWA, 1999). In this formulae, $\mathrm{N}$ represent cell abundances at incubation time $\mathrm{t}$ exposure in the extract solution, No a number of cells bacteria in control $(\mathrm{NaCl}: 0.85 \%), \mathrm{t}$ is contact time, $\mathrm{k}$ is the disinfection rate constant, $\mathrm{C}$ extract concentration and log is logarithm to base 10 .

\section{RESULTS AND DISCUSSION}

\section{Phytochemical screening of extract plant}

The phytochemical screening of Eucalyptus microcorys revealed the presence of polyphenols, sterols, triterpenoids, flavonoids, gallic tannins, anthraquinons, anthocyanins, alkaloids and saponins. The different chemical constituents of Eucalyptus microcorys leaves extract and their relative abundances are summarized in the Table 1 . Some studies revealed the presence of these compounds in other plants of the Myrtaceae family to which Eucalyptus microcorys belongs (Pamplona-Roger, 1999). The presence of hydrolysable tannins has also been reported in Eucalyptus microcorys extract (Moore et al., 2004).

Table1 Chemical constituents of Eucalyptus microcorys leaves extract

\begin{tabular}{cc}
\hline Chemical compounds tested & Appreciation of relative abundance \\
\hline Sterol and Triterpenoids & + \\
\hline Polyphenols & + \\
\hline Flavonoids & ++ \\
\hline Cathechics & - \\
\hline Gallics Tannins & + \\
\hline Anthraquinons & +++ \\
\hline Anthocyanins & ++ \\
\hline Alkaloids & ++ \\
\hline Saponins & ++ \\
\hline Lipids & -
\end{tabular}

Legend: +++: Abundant; ++: quite abundant; +: scanty; -: Non detected 


\section{Inhibition patterns and percentage of inhibition}

Figure 2(a) presents the SOM map of the cell abundances of pathogenic E. coli obtained after different incubation period at different concentrations of Eucalyptus microcorys aqueous extract solution. The Self-Organizing Map obtained was classified in the 12 output nodes, so that each node included samples with similar abundances. The Self-Organizing Map of displayed three ranges (I, II and III) of samples at different levels of the Euclidean distance. Results revealed that grouping of bacteria abundances was related to the incubation duration according to the Log ratio (G-test). Cluster I in the upperleft part of the SOM map is composed of cells abundances registered after 24 hours in the extract solution. The second Cluster in upper-right of the SOM map is made up of all cell abundances registered after 9 and 12 hours in the extract solution. Cluster III in the lower part of the SOM map is constituted by cells abundances obtained after 3 and 6 hours in the extract solution.

Figure 2(b) depicts the inhibition patterns of pathogenic E. coli for each incubation period at different light intensity and extract concentration. Dark areas represent high cell abundances, whereas the pale or bright areas represent low values of bacteria abundances. Overall, cell abundances are very low in clusters I and II at the extract concentrations $0.5 \%, 1 \%, 1.5 \%$, and $2 \%$, for $2000 \mathrm{~lx}$ and $3000 \mathrm{~lx}$ light intensity. However, there are cases where abundances remain high even after 24 hours of incubation in the extract solution in dark conditions.

The rate of cells remained after exposure to extract solution were calculated in different condition. In dark condition, the percentage of inhibition ranged between 17 and $99 \%$. The augmentation of contact time with light impact the percentage of inhibition which increase significantly. They also increased relatively with hight concentration of aqueous extract of Eucalyptus microcorys. The percentage of inhibition fluctuated between 16 à $100 \%$ under $1000 \mathrm{~lx}$, and between 38 and 100\% under $2000 \mathrm{~lx}$. The highest rate of inhibition was observed with extract concentration $0.05 \%$ after 12 hours of incubation under $3000 \mathrm{~lx}$. The presence of differents bioactive compounds in extract solution could explain the variation of inhibition rate at differents ligh intensity and incubation duration (Franco et al. 2005). In fact, compounds like flavonoids change their configuration or properties over time (Tamsa Arfao $\boldsymbol{e}$ al., 2013). This observed variation of inhibition rate could also be explained by the complexing properties (reversible and irreversible) of flavonoids. The stability and the reactivity of secondary metabolites like flavonoids are commonly linked to their molecular structures (Chebil, 2006). In addition, the variations in the percentages of inhibition could also be explained by the rapid reactivation of Escherichia coli cells in some cases which could be the result of a photo adaptation. According to Ben Sai et al. (2011), photo adaptation is able to increase tolerance to bactericidal radiation by reducing the accumulation of photo products generated at the genetic support and maintain there after cell survival.

\section{Dark $\left(K_{D}\right)$ and light $\left(K_{L}\right)$ inactivation and temperature effects}

Figure 3 depicts the variation of the hourly inhibitory rate of Escherichia coli cells with respect to each concentration of the E. microcorys leaves extract at different light intensity. (a)

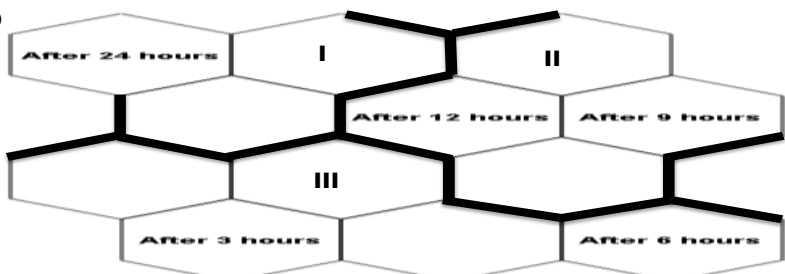

(b)

(0.05\%)
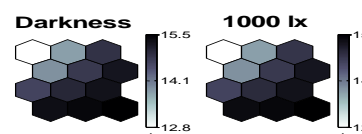

$2000 \mathrm{Ix}$

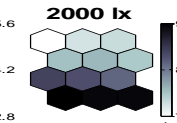

$3000 \mathrm{~lx}$

$(0.1 \%)$
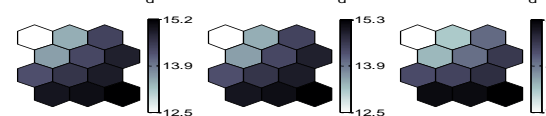

$(0.5 \%)$
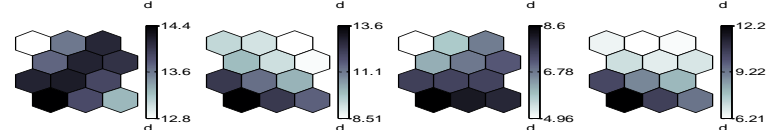

(1\%)

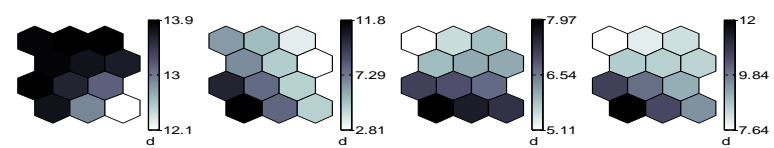

$(1.5 \%)$
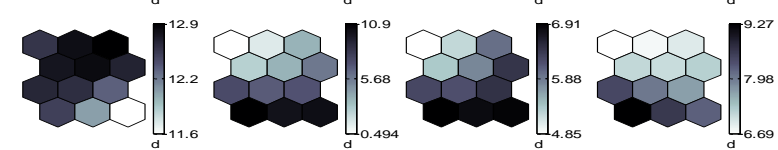

(2\%)
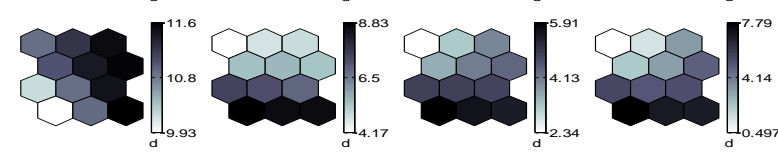

Figure 2 (a) -Clustering of samples according to their incubation duration in the Self-Organizing Map (SOM) layer. The numbers I, II and III represent different clusters; (b) - Component planes displaying the cell abundance patterns as a response to each extract concentration, at each light condition Scale bars indicate the weight vector of each parameter. Dark represents high cell abundances, whereas pale indicates low cell abundances.

After exposure to aqueous extract, dark inhibition coefficient of pathogenic Escherichia coli was respectively $0.102 \mathrm{~h}^{-1}, 0.116 \mathrm{~h}^{-1}, 0.111 \mathrm{~h}^{-1}, 0.123 \mathrm{~h}^{-1}$, $0.136 \mathrm{~h}^{-1}$ and $0.146 \mathrm{~h}^{-1}$ with $0.05 \%, 0.1 \%, 0.5 \%, 1 \%, 1.5 \%$ and $2 \%$ of extract concentration in the dark condition.

In the light condition, we noted a relative increase of $K_{L}$. Under $1000 \mathrm{~lx}$, we registered the highest value of $K_{L}\left(0.639 \mathrm{~h}^{-1}\right)$ at extract concentration $1.5 \%$. Under $2000 \mathrm{~lx}$, the highest $K_{L}\left(0,366 \mathrm{~h}^{-1}\right)$ was recorded at extract concentration $2 \%$. The lowest $K_{L}\left(0,260 \mathrm{~h}^{-1}\right)$ was recorded at extract concentration $0.1 \%$. Under $3000 \mathrm{~lx}$, the $K_{L}$ was respectively $0.343 \mathrm{~h}^{-1}, 0.361 \mathrm{~h}^{-1}, 0.394 \mathrm{~h}^{-1}, 0.300 \mathrm{~h}^{-1}$, $0.314 \mathrm{~h}^{-1}, 0.453 \mathrm{~h}^{-1}$ with $0.05 \%, 0.1 \%, 0.5 \%, 1 \%, 1.5 \%$ and $2 \%$ of extract concentration. The $K_{L}$ varied with the bacteria present in the aqueous extract solution, increasing with light intensity and aqueous extract concentration. Many studies showed that Eucalyptus species have antimicrobial activity against many bacteria (Franco et al., 2005). The essential oils of Eucalyptus camaldulensis and Eucalyptus globulus were indicated as a bactericidal or bacteriostatic agent against Escherichia coli (Ghalem and Mohamed, 2008). 


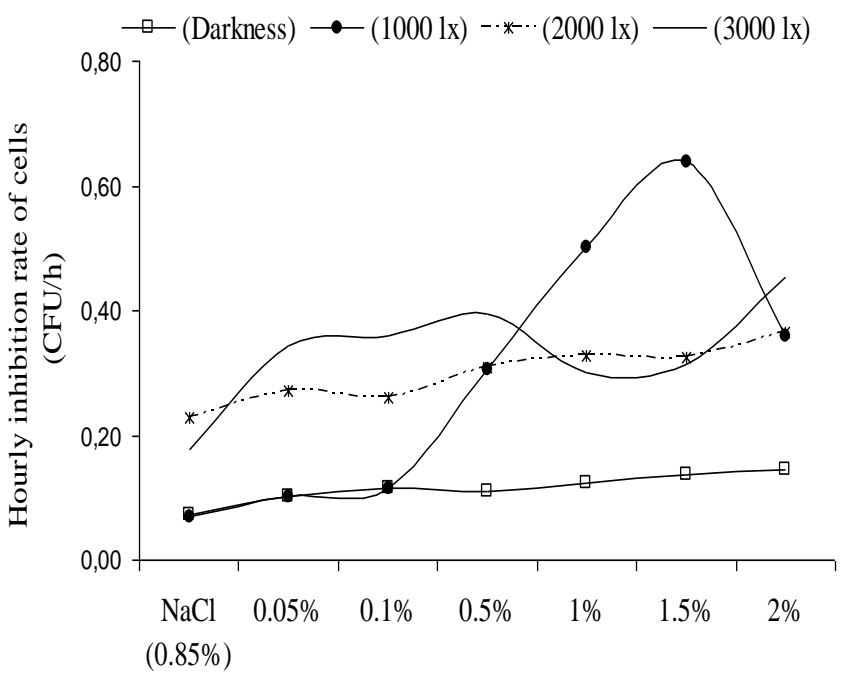

Figure 3 Variation of the hourly inhibitory rate of pathogenic E. coli cells after exposure after exposure to aqueous extract of E. microcorys

Previous study showed that aqueous extract of Eucalyptus microcorys has antibacterial activities which vary according to the type of bacteria cell and the environmental conditions (Tamsa Arfao et al., 2013). The progressive decrease of cells was noted during the conctact period with extract solution, indicating a progressive increase in the cell inhibition coefficient for fixed experimental conditions. Some authors observed that bacterial inactivation after irradiation is significatively correlated to the intensity of light (Sinton $\boldsymbol{e t}$ al., 2002).

The combined effect of light action and extract of Eucalyptus microcorys influence considerably the variation of the hourly inhibitory coefficient of cells with respect to each extract concentration (Tamsa Arfao, 2017). In fact, we noticed that the hourly inhibition coefficient is very low in dark conditions and increase with the augmentation of light intensity. Bacteria have photosensitive sites $\mathrm{P}$, which in the presence of light, are converted into reactive forms $\mathrm{P} *$. These activated forms $\mathrm{P}^{*}$ convert oxygen molecules into state singlet oxygen $\left({ }^{1} \mathrm{O}_{2}\right)$ which is a powerful oxidant and that destroys the cells (Stanier $\boldsymbol{e t}$ al. 1990). The toxicity is due to superoxide radicals and hydrogen peroxide which are produced during oxidation reactions (Nola et al., 2010). According to Maïga et al. (2009), the two major pathways involved in this process of inactivation by sunlight would be photobiological reactions (DNA alteration and oxidation of cellular elements). The presence of oxygen during exposure to light is necessary for the formation of reactive oxygen species toxic to bacteria (Jeffrey and Mitchell, 1997). The dimerization between adjacent pyrimidine bases is the most probable reaction resulting from the direct action of UV on DNA. The two major photoproducts formed are cyclobutyl pyrimidine dimer and pyrimidine (6-4) pyrimidinone. Both photoproducts inhibit DNA synthesis and gene transcription (Lilteved and Landfald, 2000). Photooxidation may also be catalyzed by exogenous photosensitizers (including photosynthetic pigments). These photosensitizers absorb in a wide range of wavelength and produce reactive oxygen species that react with the microorganisms as the bacterial cell membrane (Stracke et al., 1999). Some plants, including those used in traditional medicine to treat microbial and parasitic infections, are also able to produce singlet oxygen. These plants contain chromophore, molecules responsible for their coloring. Thus, once in the water and in the presence of a source of energy, are able to absorb energy and move from the ground state to the excited state. The stored energy is subsequently transferred to the oxygen present in the water. The passage of oxygen from the ground state to the excited or singlet state damages the microorganisms present in the water (Taba and Luwenga, 1999). It seems that, aqueous extract of Eucalyptus microcorys has a photosensitizing effect, in view of the inhibition of microorganisms in the presence of light intensity. The phytochemical screening of Eucalyptus revealed the presence of polyphenols, sterols, triterpenoids, flavonoids, tannins, anthraquinons, anthocyanins, alkaloids and saponins. These compounds are particularly photosensitizers. Polyphenols including flavonoids and tannins have antimicrobial properties which vary from one bacterial species to another (Wasserman and Murray, 1979). With light, these molecules can initiate a photosensitivity reaction generating singlet oxygen and damaging most bacteria in the medium (Bilia et al., 2006).

The photodynamic activity established could be attributed to psoralen or furocoumarins, quinones and anthraquinones compounds present to some plants (Sunda et al., 2008). Singlet oxygen is the product resulting from the action of combined photosensitizer, light and oxygen, as follows (with ISC being the Intersystem Crossing):
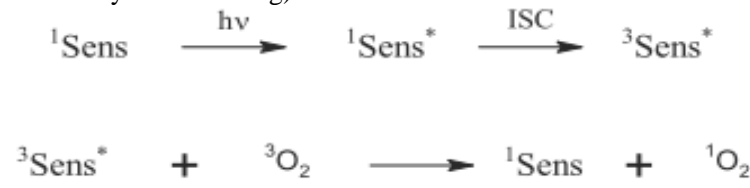

It is a form of oxygen, with a higher energy than conventional oxygen, formed by the excitation of the latter. The basic oxygen is an important participant in the photochemical processes because it contains a high chemical potential. The formation of singlet oxygen from a photosensitizing molecule begins with the excitation of the sensitizer by absorption of a photon. After intersystem crossing (ISC), the photosensitizer is in the triplet state. Triplet-triplet annihilation from oxygen in the ground state and the photosensitizer in its triplet state provides the singlet oxygen $\left({ }^{1} \mathrm{O}_{2}\right)$ and leaves the photosensitizer in its initial state (Towers, 1985). The singlet oxygen formation and its reaction are as follows:

$$
\mathrm{O}_{2}+\mathrm{e}^{-} \longrightarrow \mathrm{O}_{2}^{-}
$$

$$
\mathrm{O}_{2}^{-}+\mathrm{e}^{-}+2 \mathrm{H}^{+} \longrightarrow \mathrm{H}_{2} \mathrm{O}_{2}
$$

The triplet state reacts directly with the biological substrates (phospholipids, proteins, sterols...) by a transfer of electrons or hydrogen atoms which leads to the formation of free radical (Raven et al., 2007). These radicals can react with oxygen in the ground state to form the superoxide ion. If this case is not particularly reactive, its protonated form can however be transformed into hydrogen peroxide. The triplet state can also react directly with oxygen by transferring its excess energy to the oxygen in the ground state, moving it to triplet $\left({ }^{3} \mathrm{O}_{2}\right)$ in his singlet state $\left({ }^{1} \mathrm{O}_{2}\right)$. This singlet oxygen also reacts with the nitrogenous bases of the DNA, mainly thymine and guanine. Due to its electrophilic nature, singlet oxygen reacts with the unsaturated lipids, including cholesterol (Sunda, 2012).

During the study, we noted a change in temperature registered during the experiment. In dark condition, the temperature fluctuated between 22 and $24^{\circ}$ C. under $1000 \mathrm{~lx}$, it ranged from 38 to $42^{\circ} \mathrm{C}$. under $2000 \mathrm{~lx}$ and $3000 \mathrm{~lx}$, respectively it changed from 39 to $50^{\circ} \mathrm{C}$ and 40 to $54^{\circ} \mathrm{C}$. The increase of temperature with light intensity could also impact respectively the survival of these bacteria. Studies showed that temperature is generally involved on variation of the abundances of bacteria (Davey, 1989). Calculating the sums of square of the percentage factors, the cells inhibition of pathogenic $E$. coli is controlled by the temperature recorded during the experiment $(52.03 \%)$, followed by extract concentration $(18.79 \%)$, themselves followed by the incubation duration $(18.79 \%)$ and in turn followed by the light intensity $(0.21 \%)$. It appears clearly that the temperature $(52.03 \%)$ has a considerable effect on the inactivation of bacteria compared to the light intensity $(0.21 \%)$. Based on the data presented in the study of Tamsa Arfao et al. (2013), the temperature is a factor of great importance. It acts on biochemical reactions of microbial metabolism (Regnault, 2002). It indirectly influences the productivity of bacteria by modifying the chemical and physical characteristics of the medium (Mauguin et al., 2004). The augmentation in reaction kinetic is accompanied by an increase in metabolic wastes. However, several research projects have shown that at high temperature, there are synergistic effects between solar radiation and thermal inactivation. The temperature was merely a kinetic effect because the maximum values reached $\left(54^{\circ} \mathrm{C}\right)$ are below lethal values for fecal coliforms $\left(55^{\circ} \mathrm{C}\right)$, but in equal to the required values $\left(45^{\circ} \mathrm{C}\right)$ for the effectiveness of the synergistic effects with radiation (McGuingan et al., 1998).

The degree of connection between parameters showed a significant and negative correlation $(\mathrm{P}<0.05)$ between cell bacteria and incubation time at each extract concentration. When considering the whole incubation duration, at each experimental condition, a high significant negative correlation has been noted. The corresponding correlation matrix is presented in Tables 2 and 3.

\section{Chick-Watson model for Kinetics of Disinfection}

Chick-Watson model for different extract concentration is presented in Table 4 Globally, for extract concentration 1, 1.5 and 2\%, Chick-Watson model obtained for Eucalyptus microcorys was $\log (\mathrm{N} / \mathrm{No})=-0.1 \mathrm{Ct}$. Globally, for extract concentration $1,1.5$ and $2 \%$, Chick-Watson model obtained for 
Eucalyptus microcorys was $\log (\mathrm{N} / \mathrm{No})=-0.1 \mathrm{Ct}$. This value is very close to chlorine disinfectant $\log (\mathrm{N} / \mathrm{No})=-0.16 \mathrm{Ct}$ (YoonJin Lee et al., 2002). Sunil and Nitin (2012) obtained similar result with the plant Anjan: $\log (\mathrm{N} / \mathrm{No})=$ $0.17 \mathrm{Ct}$.

Table2 Correlation coefficients between cell bacteria and contact time at each extract concentration

\begin{tabular}{|c|c|c|c|c|c|c|}
\hline \multirow{2}{*}{ Extract concentration and cell abundances } & \multicolumn{6}{|c|}{ Correlation coefficients } \\
\hline & $0.05 \%$ & $0.1 \%$ & $0.5 \%$ & $1 \%$ & $1.5 \%$ & $2 \%$ \\
\hline Pathogenic E. coli & $-0.460^{*}$ & $-0.478^{*}$ & $-0.472 *$ & -0.371 & $-0.472 *$ & $-0.454 *$ \\
\hline
\end{tabular}

Table3 Correlation coefficients between cell bacteria and extract concentration at each experimental condition

\begin{tabular}{ccccc}
\hline Cells & \multicolumn{4}{c}{ Light intensity } \\
\cline { 2 - 5 } & $01 \mathrm{x}$ & $1000 \mathrm{~lx}$ & $2000 \mathrm{~lx}$ & $3000 \mathrm{~lx}$ \\
\hline Pathogenic $E$. coli & $-0.741^{* *}$ & $-0.734^{* *}$ & $-0.730^{* *}$ & -0.271 \\
\hline
\end{tabular}

Number of observations: $30 ; * *: \mathrm{P}<0.01$

Table 4 Chick-Watson model for different extract concentration

\begin{tabular}{ccccccc}
\hline \multirow{2}{*}{ light intensity } & \multicolumn{7}{c}{ Value of $\log (\mathrm{N} / \mathrm{No})(\mathrm{Ct})$ for each extract concentration $(\%)$} \\
\cline { 2 - 7 } & 0.05 & 0.1 & 0.5 & 1 & 1.5 & 2 \\
\hline $01 \mathrm{x}$ & $-1.1 \mathrm{Ct}$ & -0.7 & -0.1 & -0.1 & -0.1 & -0.1 \\
\hline $1000 \mathrm{~lx}$ & $-1.2 \mathrm{Ct}$ & -0.7 & -0.4 & -0.3 & -0.2 & -0.1 \\
\hline $2000 \mathrm{~lx}$ & $-0.9 \mathrm{Ct}$ & -0.5 & -0.2 & -0.1 & -0.1 & -0.1 \\
\hline $3000 \mathrm{~lx}$ & $-5.2 \mathrm{Ct}$ & -1.5 & -0.3 & -0.1 & -0.1 & -0.1 \\
\hline
\end{tabular}

\section{CONCLUSION}

The photo-inhibition of Pathogenic Escherichia coli in the aquatic microcosm increases with Eucalyptus microcorys extract in water. The photosensitivity reaction generating singlet oxygen, can improve in the presence of molecules like quinons and anthraquinons. The capture of a photon of light by a photosensitizer causes excitation of the latter. The stored energy can be transferred to the primary oxygen to generate singlet oxygen. The harmful effects of singlet oxygen on microorganisms are known. However, temperatures have a more considerable effect on the inactivation of bacteria compared to the light intensity. During the process of treatment bacterial contaminated water, it seems primordial to consider the influence of the synergistic effects between solar radiation and thermal inactivation with aqueous extract of Eucalyptus microcorys. Considering Chick-Watson model obtained, extract of Eucalyptus microcorys seems effective for inactivation of cell bacteria during water treatment.

Acknowledgments: For their contribution in qualitative phytochemical screening of Eucalyptus microcorys extract, we thank Phytobiochemistry Laboratory of Faculty of Sciences, University of Yaoundé 1.

\section{REFERENCES}

Alhoniemi, E., Himberg, J., Parankangas, J., and Vesanto, J. (2003). SOM toolbox 2.0. Laboratory of computer and information science, neural networks research center, Helsinki, Finland.

AWWA (American Water Works Association). (1999). Water Quality and treatment, 5th Edition, McGraw-Hill, New York, pp 22-32.

Ben, S M., Ben, M M., Trabelsi, D., Hassan, A., and Abdeljellil, C. (2011). Improvement of water disinfection process by UV-C irradiation. Revue des Sciences de l'eau 24 (3): 241-250. http://dx.doi.org/10.7202/1006475ar

Bergmann, H., Lourtchouk, T., Schöps, K., and Bouzek, K. (2002). New UV irradiation and direct electrolysis-promising methods for water disinfection, Chemical Engineering Journal 85: 111-117. http://dx.doi.org/10.1016/S13858947(01)00188-7

Bilia, R., Malgalhães, P., Bergonzi, C., and Vincieria F. (2006). Simultaneous analysis of artemisinin and flavonoids of several extracts of Artemisia annua L. obtained from a commercial sample and a selected cultivar. Phytomedicine 13 : 487-493. http://dx.doi.org/10.1016/j.phymed.2006.01.008

CEAEQ (Centre d'Expertise en Analyse Environnementale du Québec). (2004). Recherche et dénombrement simultanés des coliformes totaux et d'Escherichia coli dans l'eau potable avec le milieu de culture MI : méthode par filtration sur membrane. MA. 700- Ecctmi.1.0, Ministère de 1'Environnement du Québec. pp 19.

Chick, H. (1908). An investigation of the laws of disinfection. Journal of Hygiene 8, 92-158.
Chebil, L. (2006). Acylation des flavonoïdes par les lipases de Candida antarctica et de Pseudomonas cepacia : études cinétique, structurale et conformationnelle. Thèse de doctorat. Institut National Polytechnique de Lorraine. pp 229.

Davey, K. (1989). A prédictive model for combined temperature and water activity on microbial growth during the growth phase. Journal of Applied Microbiology. 67: 483-488.

Franco, J., Nakashima, T., Franco, L., and Boller, C. (2005). Chemical composition and antimicrobial in vitro activity of the essential oil Eucalyptus cinerea F. Mull. ex Benth., Myrtaceae, extracted in different time intervals. Revista Brasileira de Farmacognosia $15 \quad$ (3) : 191-194. http://dx.doi.org/10.1590/S0102-695X2005000300004

Germani, Y., and Le Bouguénec, C. (2008). Diagnostic des Escherichia coli agents de diarrhée chez l'homme. Revue francophone des Laboratoires 38 (400): 67-76. https://doi.org/10.1016/S1773-035X(08)80102-5

Ghalem, B., and Mohamed, B. (2008). Antibacterial activity of leaf essential oils of Eucalyptus globulus and Eucalyptus camaldulensis. African Journal of Pharmacy and Pharmacology. 2 (10): 211-215.

Holt, J., Krieg, N., Sneath, P., Staley, J., and William, S. 2000. Bergey's manual of determinative bacteriology. 9th Edn., Lipponcott Williams and Wilkins, Philadelphia. pp.787.

Hwang, B-F., Jakkola, J. K., and Guo, H-R .2008. Water disinfection by-products and the risk of specific birth defects: a population-based cross-sectional study in Taiwan; Environmental Health 7: 1-23. http://dx.doi.org/10.1186/1476-069X-7. 23

Jeffrey, W., and Mitchell, D. 1997. Mechanisms of UV-induced DNA damage and response in marine microorganisms. Photochemistry and Photobiology 65 (2): 261-263. http://dx.doi.org/10.1111/j.1751-1097.1997.tb08555.x

Lilteved, H., and Landfald B. 2000. Effet of high intensity light on ultravioletirradiated and non-irradiated fish pathogenic bacteria. Water Research 34 (2) 481-486. http://dx.doi.org/10.1016/S0043-1354(99)00159-1

Maïga, Y., Denyigba, K., Wethe, J., and Ouattara, S. 2009. Sunglight inactivation of Escherichia coli in waste stabilization microcosms in a sahelain region (Ouagadougou, Burkina Faso). Journal of Photochemistry and Photobiology B: Biology 94 : 113-119. http://dx.doi.org/10.1016/j.jphotobiol.2008.10.008

Mauguin, G., Delion, N., and Corsin P. (2004). La température de l'eau, un paramètre important pour la production d'eau destinée à la consommation humaine. L'eau, l'Industrie, les Nuisances 27: 23-29.

McGuingan, K., Joyce, T., Conroy, R., Gillespie, J., and Elmore-Meegan, M (1998). Solar disinfection of drinking water contained in transparent plastic bottles: characterizing the bacterial inactivation process. Journal of Applied Microbiology 84(6): 1138-1148.

Mobili, O., Lontsi, D., Tamsa, A., Nougang, M., Allahdin, O., Noah, O., Mabingui, J., Bricheux, G., Simé-Ngando, T., and Nola M. (2015). Synergistic effect of light, $\mathrm{pH}$ and Artemisia annua extract on Enterococcus faecalis in 
aquatic microcosms. International Journal of Applied Microbiology and Biotechnology Research 3: 62-72.

Moore, B., Wallis, I., Pala-paul, J., Brophy, J., Willis, R. and Foley W. (2004) Antiherbivore chemistry of Eucalyptus, cues and deterrents for marsupia folivores. Journal of Chemical Ecology, (30): 1743-1769.

\section{http://dx.doi.org/10.1023/B:JOEC.0000042399.06553.c6}

Nicolas J.P. (2012). Plantes médicinales du Nord de Madagascar Ethnobotanique antakarana et informations scientifiques. Editions Jardins du monde, pp 150.

Nola, M., Simo, M., Mobili, O., Nougang, M., Krier, F., Nour-Eddine, C., Hornez, J., and Njine, T. (2010). Photoinactivation of Staphylococcus aureus and Vibrio parahaemolyticus in the model aquatic microcosm: effect of light intensity and dissolved biodegradable organic compound, Water Science and Technology 62 (8): 1775-83. http://dx.doi.org/10.2166/wst.2010.521

Nougang, M.E., Nola, M., Ateba, B.H., Tamatcho, K.B., Noah, O.V., and Moungang, L.M. (2011). Prevalence of pathogenic strains of Escherichia coli in urban streams in the equatorial region of Cameroon (Central Africa). Journal of Applied Biosciences 48 : 3293-3305.

Pamplona-Roger, G. (1999). Encyclopedia of Medicinal Plants, 1 and 2, $\left(2^{\text {nd }}\right.$ Edn), Education and Health Library, the European Union, U.K, 128-150.

Raven, H., Evert, R., and Eichhorn, S. (2007). Biologia vegetal. 5. ed. Rio de Janeiro: Guanabara Koogan. pp 728.

Reed, R. (2004). The inactivation of microbes by sunlight: solar disinfection as a water treatment process. Advances in Applied Microbiology 54: 333-365. http://dx.doi.org/10.1016/S0065-2164(04)54012-1

Regnault, J. (2002). Eléments de microbiologie et d'immunologie. Editions Décarie. Montréal. pp 601.

Rompré, A., Servais, P., Baudart, J., De-Roubin, M., and Laurent, P. (2002)

Detection and enumeration of coliforms in drinking water: Current methods and emerging approaches. Journal of Microbiological Methods. 49: 23-29.

Sinton, L., Hall, C., Lynch, P., and Davies-Colley, R. (2002). Sunlight inactivation of fecal indicator bacteria and bacteriophages from waste stabilization pond effluent in fresh and saline waters. Applied and Environmental Microbiology. 8 : 1122-1131. DOI: 10.1128/AEM.68.3.1122-1131.2002

Sofowora A. (1993). Recent trends in research into African medicinal plants Journal of Ethnopharmacology. 38(2-3):209-214.

Stanier, R., Ingraham, J., Wheelis, M., and Painter P. (1990). General Microbiology. MacMillan, London. pp 412.

Stracke, F., Heupel, Ma Thiel E. (1999). Singlet molecular oxygen photosensitized by Rhodamine dyes: correlation with photophysical properties of the sensitizers. Journal of Photochemistry and Photobiology A: Chemistry 126 51-58. http://dx.doi.org/10.1016/S1010-6030(99)00123-9

Sunda, M. (2012). Contribution à la désinfection de l'eau par photosensibilisation avec des extraits de plantes. Thèse de doctorat, université de Liege. pp 160.

Sunda, M., Rosillon, F., and Taba, K. (2008). Contribution à l'étude de la désinfection de l'eau par photosensibilisation avec les extraits de plantes. European Journal of Water Quality 39 (2): 199- 209 http://dx.doi.org/10.4314/ijbcs.v11i1.24

Sunil, B., and Nitin, W. (2012). Formulation of kinetic model to predict disinfection of water by using natural herbs. International Journal of Environmental Sciences 2 (3): 1344-1354. http://dx.doi.org/ 10.6088/ijes.00202030021

Taba, K., and Luwenga, E. (1999). L'effet de la photosensibilisation des extraits de plantes dans la désinfection de l'eau. Mededel-Fac-Landbouw-Toegep-BiolWe, Univ. Gent 64 (1): 177-181.

Tamsa, Arfao., Nola, M., Lontsi, Djimeli., Nougang, M., Hzounda, F. (2013) Cultivability of Salmonella typhi, Vibrio cholerae and enteropathogenic Escherichia coli in water microcosm in the presence of Eucalyptus microcorys leaves extract: Effect of the concentration of leaves extract and incubation temperature. International Journal of Research in BioSciences 2 (4): 32-46.

Tamsa Arfao. A. (2017). Effet de l'extrait aqueux des feuilles d'Eucalyptus microcorys Müller, 1860 sur la cultivabilité de quelques bactéries d'importance sanitaire. Thèse de Doctorat $\mathrm{PhD}$, Université de Yaoundé 1. pp194.

Tofallis, C. (2009). Least squares percentage regression. Journal of Modern Applied Statistical Methods 7: 526-534.

Towers, G (1985). Significance of phototoxic phytochemicals in insect herbivory Jablonsky. Nature 131: 839-840.

Trease, G. and Evans, W. (1983). Orders and familys of plant in pharmacognosy. Oxford University Press, 12: 343-383.

Wasserman, H., and Murray, R. (1979). Singlet Oxygen, a series of Monographs. Academic Press New York. 40, pp 13.

Watson, H.E. (1908). A note on the variation of the rate of disinfection with change in the concentration of the disinfection. Journal of Hygiene 8: 536-542.

Weathers, P., Reed, K., Hassanali, A., Lutgen, P., and Engeu P. (2014). Whole plant approaches to therapeutic use of Artemisia аппиа L. (Asteraceae). In: Artemisia annua. Pharmacology and Biotechnology. Aftab T., Ferreira J. F. S., Khan M. M. A.\& Naeem M. eds., Springer.51-74.

WHO/UNICEF. (2010). Progress on sanitation and drinking-water 2010 Update pp 60 .
WHO. (2004). Guidelines for drinking-water quality, 3rd edition. World Health Organization, Geneva. pp 1050.

WHO. (2002). The world health report 2002 - reducing risks, promoting healthy life. pp 230.

Yoon- Jin, L., and Sang-ho, N. (2002.) Reflection on kinetic models to the chlorine disinfection for drinking water production. The Journal of Microbiology, 40(2): 119-124 